\title{
Zaburzenia snu w chorobach serca i nerek
}

\section{Sleep disorders in heart and kidney diseases}

\section{Jolanta Stępnik ${ }^{1}$, Andrzej Jaroszyński ${ }^{2}$}

${ }^{1}$ Wydział Lekarski i Nauk o Zdrowiu Uniwersytetu Jana Kochanowskiego w Kielcach

${ }^{2}$ Klinika Nefrologii, Zakład Medycyny Rodzinnej i Geriatrii Instytutu Nauk Medycznych, Uniwersytet Jana Kochanowskiego w Kielcach

\section{STRESZCZENIE}

Dotychczasowe badania i obserwacje kliniczne wskazują na związek między ilościowymi i jakościowymi zaburzeniami snu a dlugością i jakością życia. Szczególną rolę przypisuje się obturacyjnemu bezdechowi sennemu - chorobie częstej, ale zbyt rzadko rozpoznawanej i leczonej. Deprywacja snu prowadzi do rozwoju dysfunkcji śródbłonka, zwiększenia aktywności czynników prozapalnych, nasilenia zjawiska stresu oksydacyjnego, pobudzenia układu współczulnego oraz zaburzeń funkcji baroreceptorów i chemoreceptorów tętniczych. Wskutek zaburzeń snu początkowo dochodzi do rozwoju subklinicznych powikłań w obrębie naczyń, serca i nerek. Z czasem symptomy nasilają się, przybierają postać objawów klinicznych i dochodzi do zmian o charakterze wtórnym. Wspólną i dominującą cechą tych zaburzeń jest nadciśnienie tętnicze. Gorsza jakość snu może być czynnikiem zwiększającym ryzyko wystąpienia chorób układu sercowo-naczyniowego oraz sprzyjać progresji przewlekłej choroby nerek.

Choroby Serca i Naczyń 2019, 16 (3), 158-164

Stowa kluczowe: obturacyjny bezdech senny, nadciśnienie tętnicze, choroby serca i nerek

\section{ABSTRACT}

Previous studies and clinical observations indicate a relation between quantitative and qualitative sleep disorders and the length and quality of life. A special role is attributed to obstructive sleep apnea - a disease that is common, but too rarely diagnosed and treated. Sleep deprivation leads to the development of endothelial dysfunction, increased activity of pro-inflammatory factors, increased oxidative stress, stimulation of the sympathetic system and disorders of baroreceptors and arterial chemoreceptors. As a result of sleep disorders, subclinical complications in the vascular, cardiac and renal areas begin to develop. Over time, the symptoms intensify, take the form of clinical symptoms and secondary changes occur. A common and dominant feature of these disorders is arterial hypertension. Lower quality of sleep may increase the risk of cardiovascular diseases and promote the progression of chronic kidney disease.

Choroby Serca i Naczyń 2019, 16 (3), 158-164 Key words: obstructive sleep apnea, hypertension, heart and kidney diseases

Adres do korespondencji:

lek. Jolanta Stepnik

Wydział Lekarski i Nauk o Zdrowiu

Uniwersytet Jana Kochanowskiego w Kielcach

al. IX Wieków Kielc 19, 25-001 Kielce

e-mail: jolantastepnik@gmail.com 


\section{WPROWADZENIE}

Zaburzenia snu i czuwania obejmują wiele nieprawidłowości związanych z bezsennością, nadmierną sennością, narkolepsją, zaburzeniami oddychania podczas snu, nieprawidłowym okołodobowym rytmem snu i czuwania. Obejmują także zaburzenia związane $\mathrm{z}$ wybudzaniem w czasie snu bez szybkich ruchów gałek ocznych (non-REM, non-rapid eye movement), koszmary senne, nieprawidłowe zachowania w czasie snu REM oraz zespół niespokojnych nóg [1]. Bezsennośćjest najpowszechniejszą chorobą spośród wszystkich zaburzeń snu. Szacuje się, że 10-20\% pacjentów podstawowej opieki zdrowotnej (POZ) zgłasza objawy bezsenności, spośród których 10-15\% doświadcza także pogorszenia funkcjonowania w ciągu dnia. Bezsenność częściej występuje u kobiet niż u mężczyzn, proporcje wynoszą 1,44:1 [2,3]. Chociaż bezsenność może być objawem albo niezależnie występującą chorobą, to najczęściej obserwuje się ją jako dolegliwość współwystępującą z inną chorobą somatyczną lub psychiczną [1].

Szczególne znaczenie w podejmowanych badaniach mają jakościowe zaburzenia oddychania podczas snu, a wśród nich schorzenie, jakim jest obturacyjny bezdech senny (OSA, obstructive sleep apnoea) [4]. Zespół bezdechu sennego jest jednym z najczęstszych elementów grupy schorzeń określanych jako zaburzenia oddychania podczas snu. Mianem bezdechu określa się przerwę w oddychaniu trwającą co najmniej 10 sekund (sygnał toru oddychania musi wynosić $<10 \%$ referencyjnej amplitudy). Z kolei jako spłycenie oddychania definiuje się zmniejszenie przepływu o co najmniej $30 \%$, z desaturacją ograniczoną o co najmniej 4\%. W praktyce klinicznej używa się określenia wskaźnik bezdechów i spłyceń oddychania (AHI, apnea-hypopnea index), który opisuje liczbę zaburzeń w ciągu godziny będącą wykładnikiem nasilenia zaburzeń oddychania podczas snu. Wskaźnik wyrażany skrótem RDI (respiratory disturbance index) określa liczbe nieuświadamianych przez chorego przebudzeń w nocy, spowodowanych chorobą. Obturacyjny bezdech senny wiąże się z nawracającymi epizodami całkowitego zapadania lub zwężenia górnych dróg oddechowych, które następują na poziomie gardła, na którym — z wyjątkiem tylnej ściany — brakuje sztywnego podparcia. Znamienne dla tego procesu jest zachowanie ruchów klatki piersiowej i brzucha [5]. Wzrastające napięcie mięśni górnych dróg oddechowych oraz gwałtowne otwieranie się gardła skutkuje wibracją okolicznych tkanek miękkich, która objawia się chrapaniem. Na skutek powtarzających się sekwencji zdarze, dochodzi niekiedy do często nieuświadomionego przebudzenia, oraz, co jest istotne kliniczne, do niedotlenienia $[6,7]$.

Zaburzenia snu dotyczą znacznej grupy ludzi i pozostają problemem o dużym znaczeniu zarówno społecznym, jak i klinicznym. Dotyczą wielu aspektów życia chorych. Ważnym zadaniem badaczy i klinicystów jest zidentyfikowanie schorzeń związanych z zaburzeniami snu, określenie ogniw pośrednich, patogenezy oraz relacji i procesów mogących rzutować na rozwój następstw i konsekwencji zaburzeń [8].

\section{ZNACZENIE SNU}

Sen jest jedną z naturalnych potrzeb człowieka, niezbędną do prawidłowego funkcjonowania w ciągu dnia. Spokojny, niczym niezakłócony sen to prawdopodobnie główny czynnik prozdrowotny, w znaczącym stopniu determinujący długość i jakość życia [9]. Jak istotny jest sen i jakie ma znaczenie dla życia człowieka, pokazały wyniki badań nad deprywacją snu u szczurów. Na drodze eksperymentów udowodniono, że całkowite pozbawienie snu doprowadziło do śmierci wszystkie badane zwierzęta w ciągu 2-3 tygodni [10]. Zaburzenia snu nie tylko utrudniają pacjentom odpoczynek i regenerację organizmu. Mogą być również groźne dla życia, stanowiąc źródło lub skutek poważnej choroby. W metaanalizie badań prospektywnych wykazano, że zarówno długi, jak i krótki okres snu wiążą się z wyższym ryzykiem cukrzycy, otyłości, częstszym występowaniem chorób układu sercowo-naczyniowego oraz powikłań w postaci nefropatii, mikroangiopatii oraz makroangiopatii [11]. Zaburzeniom snu i czuwania towarzyszą także uczucie zmęczenia i gorsze funkcjonowanie w ciągu dnia. Choć problem w znaczący sposób obniża jakość życia pacjenta i jego rodziny, to często pozostaje bagatelizowany. Nieleczony przyczynia się do licznych, często poważnych problemów zdrowotnych [12].

\section{PODZIAK ZABURZEŃ SNU}

Wśród licznych objawów nieprawidłowego snu wyróżnia się zaburzenia związane $\mathrm{z}$ dyssomniami, parasomniami oraz zaburzenia snu towarzyszące innym zdrowotnym nieprawidłowościom [1]. Istotną część stanowią zaburzenia snu związane z nocną dysfunkcją oddechową. Zaburzenia oddychania w czasie snu (SRBD, sleep-related breathing disorder) to niejednorodna grupa chorób o zbliżonym obrazie klinicznym, ale różnej patogenezie. Polskie Towarzystwo Chorób Płuc (PTChP), na podstawie 
wytycznych American Academy of Sleep Medicine (AASM), w 2013 roku przyjęło klasyfikację SRBD, w ramach której wyróżnia się następujące jednostki chorobowe [7]:

- centralny bezdech senny - może być związany z oddychaniem Cheyne'a-Stokesa lub innymi chorobami, z oddychaniem okresowym na dużej wysokości, idiopatyczny, polekowy, oraz pierwotny bezdech senny u niemowląt;

- OSA u dorosłych i u dzieci;

- zespół hipowentylacji i hipoksemii w czasie snu idiopatyczna hipowentylacja pęcherzykowa, niezwiązana z obturacją dróg oddechowych, wrodzona centralna hipowentylacja pęcherzykowa;

- zespół hipowentylacji i hipoksemii pęcherzykowej $\mathrm{w}$ czasie snu związany z innymi chorobami: $\mathrm{w}$ przebiegu chorób śródmiąższowych płuc i naczyń płucnych, w przebiegu chorób nerwowo-mięśniowych i chorób ściany klatki piersiowej, związany z obturacją dolnych dróg oddechowych;

- SRBD niesklasyfikowane gdzie indziej.

Obturacyjny bezdech senny jest najczęstszą postacią zaburzeń oddychania w czasie snu i stanowi $(90 \%)$ wszystkich zaburzeń $[13,14]$.

\section{MECHANIZM ROZWOJU NADCIŚNIENIE TĘTNICZEGO ORAZ CHORÓB UKLADU SERCOWO-NACZYNIOWEGO}

W wielu obserwacjach klinicznych dowiedziono istnienia ścisłego związku między występowaniem bezdechów w czasie snu a zwiększoną zachorowalnością i przyspieszeniem progresji chorób układu sercowo-naczyniowego. Chociaż patofizjologia zaburzeń jest procesem złożonym i zależy od różnorodnych czynników, to główny związek dotyczy rozwoju nadciśnienia tętniczego [15-17].

Prawidłowe funkcjonowanie układu krążenia wiąże się z dobowym rytmem aktywności i odpoczynku. Zaburzenie architektoniki snu oraz epizody bezdechu przyczyniają się do powstawania hipoksemii. Retencja dwutlenku węgla powoduje nasilenie reakcji układu współczulnego i stymulację ośrodków oddechowych, co skutkuje zwiększeniem liczby i głębokości oddechów, a w efekcie wzrostem wentylacji minutowej oraz przyspieszeniem rytmu serca $[18,19]$. Inflacja płuc i zwiększanie objętości klatki piersiowej, poprzez stymulację nerwu błędnego, łagodzą zwiększoną aktywność układu współczulnego, co sprzyja utrzymaniu homeostazy. Podczas powtarzających się epizodów bezdechu układ współczulny nie jest hamowany w sposób fizjologiczny, co sprzyja utrzymywaniu nadmiernej reakcji na niedotlenienie, również w ciągu dnia, gdy hipoksja nie występuje $[18,20,21]$.

Patomechanizm nadciśnienia tętniczego w przebiegu bezdechu sennego jest procesem bardzo złożonym i, mimo wielu badań, nie do końca poznanym. Jednak istnieją dowody na to, że kluczową rolę w jego powstawaniu mogą odgrywać upośledzona funkcja baroreceptorów i chemoreceptorów tętniczych, dysfunkcja śródbłonka oraz zwiększone stężenia endoteliny. Endotelina działa poprzez łączenie się ze specyficznymi receptorami. Jej czynność polega na regulacji naczyniowego oporu obwodowego, przyspieszaniu rytmu serca oraz zwiększeniu aktywacji współczulnego układu nerwowego. Główną rolą endoteliny jest utrzymywanie właściwego napięcia naczyń. Wykazuje ona również działania mitogenne, proagregacyjne i aterogenne. Odgrywa ponadto istotną rolę w utrzymywaniu stanu dynamicznej równowagi między substancjami zwężającymi naczynia (np. kalcytoniną) oraz rozszerzającymi naczynia (np. tlenkiem azotu, prostacykliną) $[18,19,22]$. Potwierdzono, że w czasie kilkugodzinnego snu u nieleczonych pacjentów z OSA stężenie endoteliny wzrasta. Zmiana ta koreluje ze wzrostem ciśnienia tętniczego, a także spadkiem saturacji. Ponadto dowiedziono, że po trwającym 4 godziny leczeniu stałym dodatnim ciśnieniem $\mathrm{w}$ drogach oddechowych (CPAP, continuous positive airway pressure) następuje obniżenie wartości endoteliny, co implikuje jej rolę w patogenezie nadciśnienia tętniczego u pacjentów z OSA [18].

Niektórzy badacze zwracają uwagę na rolę przedsionkowego peptydu natriuretycznego (ANP, atrial natriuretic peptide) jako czynnika regulującego ciśnienie tętnicze. Przedsionkowy peptyd natriuretyczny jest substancją wydzielaną przez komórki mięśniowe przedsionków serca w odpowiedzi na ich rozciąganie [21]. Dzięki swoim właściwościom ANP wpływa na wydalanie wody i sodu w nerkach, przez co reguluje objętość krwi krążącej i działa rozkurczająco na ściany naczyń, zwiększając w ten sposób objętość łożyska naczyniowego. Zmiany objętości wewnątrznaczyniowej, poprzez zwiększanie obciążenia wstępnego lewej komory, współwystępujące z podwyższonym obciążeniem następczym, stanowią główny czynnik prowadzący do zwiększania objętości rozkurczowej komory i stymulacji przerostu ścian [21, 23]. W badaniach epidemiologicznych znajduje potwierdzenie fakt, że pacjenci obciążeni OSA częściej chorują na nadciśnienie tętnicze. Jednocześnie w populacji osób 
z nadciśnieniem tętniczym częściej rozpoznaje się bezdech senny $[19,24]$.

Ważnym czynnikiem oznak rozwoju zapalenia na wczesnym etapie zmian jest obecność selektyn. Działają one zawsze w połączeniu ze śródbłonkiem [25]. Ich zasadniczą funkcją, w przeciwieństwie do funkcji innych cząsteczek adhezyjnych, jest przyłączanie leukocytów do śródbłonka. W wielu badaniach stwierdzono, że selektyny pośredniczą w toczeniu neutrofilów, monocytów i limfocytów do ściany naczyń krwionośnych. Realizując tę funkcję, selektyny pełnią kluczową rolę w rekrutacji leukocytów do ogniska zapalnego [25, 26]. Umiejscowione na przemieszczających się leukocytach łączą się z ligandami obecnymi na powierzchni komórek śródbłonka. W ten sposób dochodzi do aktywacji leukocytów, wytwarzania przez nie szeregu cytokin prozapalnych, a także aktywacji integryn. Proces ten sprzyja rozwojowi silnych połączeń między leukocytami i komórkami śródbłonka. Powstają warunki sprzyjające migracji leukocytów przez ścianę naczyń krwionośnych i dotarciu do środowiska zapalnego, dzięki czemu może być realizowana reakcja obronna organizmu przed czynnikami zapalnymi.

W trakcie bezdechów wahaniom ulega ciśnienie wewnątrz klatki piersiowej. Sporadycznie osiąga ono wartości ujemne, co w połączeniu z gwałtownymi wyrzutami katecholamin do krwioobiegu, a także zwiększoną aktywnością układu adrenergicznego, powoduje stopniowy przerost lewej komory i przebudowę przedsionka. Proces ten zwiększa ryzyko wystąpienia niewydolności serca, niedokrwienia mięśnia sercowego oraz sprzyja powstawaniu arytmii, zahamowań zatokowych i bloków przedsionkowo-komorowych [13, 23, 27]. Przyczyny zaburzeń przewodnictwa u pacjentów z OSA pozostają niewyjaśnione. Zastosowanie aparatów do wytwarzania CPAP zapobiega wystąpieniu zaburzeń przewodzenia u ponad 90\% chorych, co wskazuje na ścisły związek między OSA a zaburzeniami rytmu serca [23].

W dużym badaniu z początku lat 90. XX wieku The Sleep Health Heart Study potwierdzono, że OSA stanowi niezależny czynnik rozwoju choroby wieńcowej oraz zawału serca, a jego wpływ jest bardziej znaczący niż nadciśnienia tętniczego, palenia tytoniu, hipercholesterolemii i otyłości. Udowodniono, że u chorych z AHI ponad 30 ryzyko zawału jest 23 razy wyższe niż u zdrowych osób palących tytoń $[23,28]$. W wielu badaniach $z$ ostatnich lat dotyczących zaburzeń snu i ich wpływu na zdrowie pacjentów uzyskano wyniki potwierdzające, że OSA jest związany z obecnością zwiększonych stężeń wielu spośród mediatorów włączonych w procesy przewlekłego zapalenia, przyczynia się do powstawania stresu oksydacyjnego oraz wzmaga działanie prokoagulacyjne [16-18, 20, 29].

\section{ZABURZENIA SNU JAKO CZYNNIK INDUKUJĄCY PROGRESJĘ PRZEWLEKLEJ CHOROBY NEREK}

Zaburzenia snu, głównie o cechach i charakterze OSA, często towarzyszą przewlekłej chorobie nerek (CKD, chronic kidney disease). Chociaż związek obu chorób nie jest do końca wyjaśniony, to istnieją dowody na to, że leczenie CPAP przynosi efekty terapeutyczne oraz poprawia rokowanie $\mathrm{u}$ chorych z CKD. W badaniach potwierdzono również wzajemną zależność, nasilanie i interakcje obu chorób. W rzeczywistości OSA może być konsekwencją CKD, a także czynnikiem przyspieszającym progresję uszkadzania nerek [8].

W związku ze wspólną etiopatogenezą każdy z czynników predysponujących do OSA, takich jak: nadciśnienie tętnicze, wzrost aktywności współczulnego układu autonomicznego, aktywacja kaskady enzymatyczno-hormonalnej układu renina-angiotensyna-aldosteron (RAA), dysfunkcja śródbłonka naczyniowego, zwiększony stres oksydacyjny, zapalenie ogólnoustrojowe, zwiększona agregacja płytek, otyłość, insulinooporność i zaburzenia metaboliczne, jest również czynnikiem ryzyka i progresji CKD [30, 31]. Pacjentów z OSA cechuje zatem wysoka częstość występowania CKD, i odwrotnie - pacjenci z CKD częściej chorują na OSA.

Obturacyjny bezdech senny pośredniczy w uszkodzeniu nerek na drodze kilku mechanizmów. Istotną rolę mogą ogrywaćizolowany wzrost ciśnienia skurczowego, brak naturalnego spadku ciśnienia tętniczego w nocy (lub jego wzrost), a także utrzymywanie się podwyższonych wartości ciśnienia w ciągu dnia. Obturacyjny bezdech senny uznano za przyczynę nadciśnienia wtórnego. Dobrze znaną konsekwencją nadciśnienia tętniczego jest zwiększona sztywność tętnic, co prowadzi do mikrouszkodzeń naczyń krwionośnych i pogorszeniem funkcji nerek [22, 31]. W wielu badaniach wykazano związek między AHI a nadciśnieniem tętniczym. Dowiedziono, że leczenie OSA za pomocą CPAP obniża ciśnienie tętnicze, zaś kontrola ciśnienia zmniejsza częstość upośledzenia funkcji nerek [22, 32]. Towarzyszącą nadciśnieniu hiperfiltrację kłębuszkową często uznaje się za przyczynę progresji CKD. W wielu badaniach udowodniono, że terapia CPAP zmniejsza przesączanie kłębuszkowe, co zapobiega rozwojowi nefropatii [22,33]. 
Zwiększona aktywność układu współczulnego to kluczowy mechanizm, w którym OSA przyczynia się do nadciśnienia tętniczego. Powtarzające się epizody hipoksemii spowodowane OSA pobudzają układ współczulny, co w konsekwencji zwiększa opór naczyniowy i indukuje aktywację układu RAA [34, 35]. Obecność wszystkich składników układu RAA w nerkach może doprowadzić do ograniczenia przepływu krwi przez nerkę oraz obniżenia filtracji kłębuszkowej przez skurcz tętniczek doprowadzających i odprowadzających [36]. Pacjenci z OSA cechują się zwiększonymi stężeniami aldosteronu i dezoksykortykosteronu w surowicy krwi. Aldosteron powoduje zaburzenie produkcji tlenku azotu oraz pobudza aktywność oksydaz i syntezy kolagenu. Oba mineralokortykoidy nadnerczy powodują zwiększenie resorpcji sodu i sekrecję potasu, co również zwiększa ciśnienie tętnicze i przyczynia się do stwardnienia kłębuszków nerkowych i zwłóknienia nerek [32, 35]. Działanie obydwu hormonów powoduje uszkodzenie tkanki narządu, rozwój stanu zapalnego i włóknienia w wyniku generacji wolnych rodników tlenowych i aktywacji cytokin prozapalnych. W publikacjach z ostatnich lat potwierdzono istotny udział reniny $\mathrm{i}$ aldosteronu $\mathrm{w}$ progresji CKD [33]. Od dawna znana jest także rola angiotensyny II (Ang II) w rozwoju nadciśnienia tętniczego i ogólnoustrojowego zapalenia. Obecność wszystkich składników układu RAA w nerkach oraz receptora typu 1 dla Ang II w tętniczkach nerkowych, komórkach mezangium ciałka nerkowego i kanalikach bliższych wskazuje na duże znaczenie wewnątrznerkowego układu RAA jako czynnika parakrynnie regulującego funkcję nerek [32].

Istotną rolę $\mathrm{w}$ przewlekłej nefropatii przypisuje się cytokinom będącym mediatorami stanu zapalnego. Cytokiny prozapalne są uwalniane $\mathrm{w}$ wyniku działania na nerki czynników uszkadzających. Dochodzi do powstania nacieku zapalnego w miąższu nerek, pobudzenia fibroblastów i rozwoju włóknienia. Dowiedziono, że najistotniejszą rolę w rozwoju i postępie nefropatii pełni transformujący czynnik wzrostu beta ${ }_{1}$ (TGF- $\beta_{1}$, transforming growth factor beta ${ }_{1}$ ) będący najważniejszym czynnikiem pobudzającym włóknienie i kluczowym mediatorem uszkodzenia podocytów wyścielających zewnętrzną powierzchnię błony podstawnej kłębuszka nerkowego. W badaniach prowadzonych w ostatnich latach potwierdzono istotnie wyższe stężenie wielu cytokin pozapalnych w surowicy krwi u pacjentów z CKD, przy niezmienionych wartościach cytokin przeciwzapalnych [37-39]. Obturacyjny bezdech senny jest częstym pro- blemem klinicznym u chorych na CKD. Chociaż dane są ograniczone, to OSA wydaje się zmieniać hemodynamikę nereki upośledzaćich funkcję. Istnieje potrzeba dalszych badań w celu lepszego poznania mechanizmów, za pomocą których OSA może prowadzić do progresji CKD.

\section{INNE CHOROBY TOWARZYSZACE ZABURZENIOM SNU}

Z powodu powtarzającej się hipoksemii w OSA dochodzi do hipoksji tkanki, aktywacji układu współczulnego, wzrostu wydzielania leptyny, czynnika martwicy nowotworów alfa (TNF- $\alpha$, tumor necrosis factor alpha) interleukiny 6 (IL-6, interleukin 6) oraz pobudzenia czynności osi podwzgórze-przysadka-kora nadnerczy, co większa wydzielanie kortyzolu. Pobudza to glikogenolizę, glukoneogenezę, wydzielanie glukagonu, lipolizę, a także powoduje wzrost stężenia wolnych kwasów tłuszczowych. Dochodzi do rozwoju insulinooporności oraz zaburzenia tolerancji glukozy, co usposabia do rozwoju cukrzycy i otyłości [40-42]. Z badań epidemiologicznych wynika, że wśród pacjentów z OSA 70\% stanowią osoby otyłe. Wykazano także, że przyrost masy ciała o 10\% 6-krotnie zwiększa ryzyko zachorowania na OSA. U około połowy wszystkich chorych na cukrzycę rozwija się CKD $[3,40]$.

Nie tylko zaburzenia jakościowe snu pełnią rolę w patogenezie opisanych wyżej chorób. Zarówno obniżona jakość, jaki ilość snu, wskutek zaburzeń autonomicznego układu nerwowego, powoduje nasilenie wydzielania glikokortykoidów oraz podwyższenie stężenia glukozy we krwi [41]. Eksperymenty ze skróceniem snu potwierdzają obniżenie wrażliwość na insulinę, zmniejszenie tolerancji glukozy, zwiększenie stężenia cholesterolu całkowitego i frakcji lipoprotein o wysokiej gęstości (HDL, high-density lipoproteins). Krótki sen można więc powiązać z cukrzycą, hipercholesterolemią i otyłością oraz występowaniem zespołu metabolicznego [29, 42]. Związek występowania otyłości z długością snu skojarzono z mechanizmami działania glukozy i insuliny oraz leptyny i greliny, a także ze zwiększonym spożyciem kilokalorii i mniejszą aktywnością fizyczną. Grelina i leptyna są hormonami, które odgrywają ważną rolę w metabolizmie, głównie węglowodanów i lipidów. Grelina jest wydzielana w określonym rytmie dobowym, przede wszystkim w godzinach nocnych. Zwiększa wychwyt glukozy oraz produkcję hormonów stresu, jakimi są kortyzol i adrenalina. Wpływa również na wzrost stężenia glukagonu i obniżenie wydzielania insuliny, zatem wspomaga proces glukoneogenezy oraz wpływa na zwiększenie lipogenezy w organizmie [43]. Hamuje wydzielanie adiponektyny, która 
z kolei obniża wartości triglicerydów i cholesterolu, przez co zaburza gospodarkę lipidową. Niedobór snu wpływa na zwiększenie wydzielania tych hormonów, dlatego też osoby z niedoborami snu mają większą tendencję do otyłości. Ponadto istnieje zależność między stresem a stężeniem greliny we krwi, a także stężeniem greliny a wskaźnikiem masy ciała (BMI, body mass index). Im silniejszy stres lub niższy BMI, tym wyższa wartość greliny we krwi [31, 43, 44]. Te i inne czynniki mogą wyjaśniać podstawowe mechanizmy zwiększenia masy ciała u osób z zaburzeniami snu. Brak snu wiąże się także ze zwiększonym uczuciem głodu, przyczyniając się do zwiększenia spożycia, zwłaszcza słonych przekąsek. Pogarszająca się jakość i ilość snu może więc indukować otyłość oraz zwiększać ryzyko wystąpienia chorób związanych z otyłością, takich jak cukrzyca, nadciśnienie tętnicze i choroby układu sercowo-naczyniowego, nefropatia i CKD [45].

\section{PODSUMOWANIE}

Nadciśnienie tętnicze, choroby serca, CKD oraz zaburzenia metaboliczne mają wspólną patofizjologię, są ze sobą powiązane i bardzo rozpowszechnione w grupie pacjentów z zaburzeniami snu. U chorych na CKD częściej niż u osób zdrowych diagnozuje się OSA. Istnieją wystarczające dowody pozwalające twierdzić, że leczenie zaburzeń snu wpływa na obniżenie ciśnienia tętniczego i może spowolnić progresję CKD. Obturacyjny bezdech senny sprzyja występowaniu nadciśnienia tętniczego i chorób serca oraz inicjuje i przyspiesza postęp CKD. Wskutek wzajemnych reakcji i dwukierunkowych powiązań CKD i choroby serca nasilają zaburzenia snu i objawy OSA. Niniejsze opracowanie jest próbą oceny znaczenia snu w chorobach serca i nerek oraz poznanie patogenezy i roli mechanizmów zaangażowanych we wzajemny proces rozwoju tych schorzeń.

\section{KONFLIKT INTERESÓW}

Autorzy nie zgłaszają konfliktu interesów.

\section{PIŚMIENNICTWO}

1. American Psychiatric Association. Zaburzenia snu i czuwania. Wybrane kategorie DSM-5. Wydanie I polskie (red. Skalski M.). Edra Urban \& Partner, Wrocław 2015

2. Jee D, Keum N, Kang S, et al. Sleep and diabetic retinopathy. Acta Ophthalmol. 2017; 95(1): 41-47, doi: 10.1111/aos.13169, indexed in Pubmed: 27473575.

3. Meng LL, Liu Y, Geng RN, et al. Association of diabetic vascular complications with poor sleep complaints. Diabetol Metab Syndr. 2016; 8: 80, doi: 10.1186/s13098-016-0195-8, indexed in Pubmed: 27980688.

4. Cofta S. Ocena wpływu stopnia ciężkości obturacyjnego bezdechu sennego na wybrane wykładniki nasilenia procesów patogenetycz- nych z uwzględnieniem selektyn i stresu oksydacyjnego. Wydawnictwo Naukowe Uniwersytetu Medycznego im. Karola Marcinkowskiego w Poznaniu, Poznań 2013

5. Jóźwik-Plebanek K, Prejbisz A, Janaszek-Sitkowska H, et al. Obturacyjny bezdech senny a powikłania w układzie sercowo-naczyniowym. Kardiol Pol. 2012; 70(7): 735-740.

6. Cofta S. Zespół bezdechu sennego. In: Batura-Gabryel H. ed. Kompendium pulmonologiczne. Wydawnictwo Naukowe Uniwersytetu Medycznego im. Karola Marcinkowskiego w Poznaniu, Poznań 2013: 315-324.

7. Pływaczewski R, Brzecka A, Bielicki P, et al. Zalecenia Polskiego Towarzystwa Chorób Płuc dotyczące rozpoznawania i leczenia zaburzeń oddychania w czasie snu u dorosłych. Pneumonol Alergol Pol. 2013; 81(3): 221-258

8. Yayan J, Rasche K, Vlachou A. Obstructive sleep apnea and chronic kidney disease. Adv Exp Med Biol. 2017; 1022: 11-18, doi: 10.1007/5584 2017 35, indexed in Pubmed: 28567615.

9. Skalski M. Zaburzenia oddychania w codziennej praktyce. Medical Tribune Polska, Warszawa 2012

10. Rechtschaffen A, Bergmann BM, Everson CA, et al. Sleep deprivation in the rat: X. Integration and discussion of the findings. Sleep. 1989; 12(1): 68-87, indexed in Pubmed: 2648533.

11. Cappuccio FP, D'Elia L, Strazzullo P, et al. Quantity and quality of sleep and incidence of type 2 diabetes: a systematic review and meta-analysis. Diabetes Care. 2010; 33(2): 414-420, doi: 10.2337/ /dc09-1124, indexed in Pubmed: 19910503.

12. Chruściel-Nogalska M, Kozak M, Ey-Chmielewska H. Zespół obturacyjnego bezdechu podczas snu - podstawy diagnostyki i leczenia. Dental Forum. 2015; 43: 65-69.

13. Kiciński P, Zakrzewski M, Dybała A, et al. Obturacyjny bezdech senny - zasady diagnostyki i leczenia. Forum Med Rodz. 2012; 6(5): 228-235.

14. Hasiec A, Szumowski $Ł$, Walczak F. Obturacyjny bezdech — senny zabójca. Forum Med Rodz. 2012; 6(3): 103-114

15. Binko P, Wysokiński A. Obturacyjny bezdech senny i jego związek z nadciśnieniem tętniczym - wciąż aktualny temat. Choroby Serca Naczyń. 2018; 15(4): 226-231.

16. Kanarek J, Wolf J, Narkiewicz K. Obturacyjny bezdech senny jako czynnik ryzyka chorób układu krążenia. Choroby Serca i Naczyń. 2014; 11(2): 65-70

17. Wolf J, Narkiewicz K. Zespół bezdechu sennego a choroby układu krążenia. Choroby Serca i Naczyń. 2007; 4(1): 40-47.

18. Ahmad M, Makati D, Akbar S. Review of and updates on hypertension in obstructive sleep apnea. Int J Hypertens. 2017; 2017: 1848375, doi: 10.1155/2017/1848375, indexed in Pubmed: 29147581.

19. Nieto FJ, Young TB, Lind BK, et al. Association of sleep-disordered breathing, sleep apnea, and hypertension in a large community-based study. Sleep Heart Health Study. JAMA. 2000; 283(14): 1829-1836, doi: 10.1001/jama.283.14.1829, indexed in Pubmed: 10770144.

20. Tamisier R, Pépin JL, Rémy J, et al. 14 nights of intermittent hypoxia elevate daytime blood pressure and sympathetic activity in healthy humans. Eur Respir J. 2011; 37(1): 119-128, doi: 10.1183/09031936.00204209, indexed in Pubmed: 20525723.

21. Aziz F, Chaudhary K. The triad of sleep apnea, hypertension, and chronic kidney disease: a spectrum of common pathology. Cardiorenal Med. 2016; 7(1): 74-82, doi: 10.1159/000450796, indexed in Pubmed: 27994605

22. Ozkok A, Kanbay A, Odabas AR, et al. Obstructive sleep apnea syndrome and chronic kidney disease: a new cardiorenal risk factor. Clin Exp Hypertens. 2014; 36(4) : 211-216, doi: 10.3109/10641963.2013. 804546, indexed in Pubmed: 24432915.

23. Myśliński W, Dybała A, Mosiewicz J. Zaburzenia czynności układu sercowo-naczyniowego u chorych z zespołem obturacyjnego bezdechu sennego. Wiad Lek. 2005; 58(1-2): 78-83.

24. Dewan NA, Nieto FJ, Somers VK. Intermittent hypoxemia and OSA: implications for comorbidities. Chest. 2015; 147(1): 266-274, doi: 10.1378/chest.14-0500, indexed in Pubmed: 25560865. 
25. Zerdziński M, Rychlik M, Partyka R. The selectins role in the development of inflammatory response. Journal of Laboratory Diagnostics. 2012; 48(3): 347-351.

26. Abdulla A, Awla D, Hartman $\mathrm{H}$, et al. Platelets regulate P-selectin expression and leukocyte rolling in inflamed venules of the pancreas. Eur J Pharmacol. 2012; 682(1-3): 153-160, doi: 10.1016/j. ejphar.2012.02.014, indexed in Pubmed: 22374261.

27. Bradley TD, Floras JS. Obstructive sleep apnoea and its cardiovascular consequences. Lancet. 2009; 373(9657): 82-93, doi: 10.1016/ /S0140-6736(08)61622-0, indexed in Pubmed: 19101028.

28. Hung J, Whitford EG, Parsons RW, et al. Association of sleep apnoea with myocardial infarction in men. Lancet. 1990; 336(8710) : 261-264, doi: 10.1016/0140-6736(90)91799-g, indexed in Pubmed: 1973968.

29. Gangwisch JE. A review of evidence for the link between sleep du ration and hypertension. Am J Hypertens. 2014; 27(10): 1235-1242, doi: 10.1093/ajh/hpu071, indexed in Pubmed: 24778107.

30. Caballo C, Palomo M, Cases A, et al. NFкB in the development of endothelial activation and damage in uremia: an in vitro approach. PLoS One. 2012; 7(8): e43374, doi: 10.1371/journal.pone.0043374, indexed in Pubmed: 22937042.

31. Ramirez JM, Garcia AJ, Anderson TM, et al. Central and peripheral factors contributing to obstructive sleep apneas. Respir Physiol Neurobiol. 2013; 189(2): 344-353, doi: 10.1016/j.resp.2013.06.004, indexed in Pubmed: 23770311.

32. Stompór T, Rutkowski B, Biedunkiewicz B, et al. (Grupa PChN). Białkomocz. Forum Nefrol. 2009; 2(1): 50-59

33. Peralta CA, Jacobs DR, Katz R, et al. Association of pulse pressure, arterial elasticity, and endothelial function with kidney function decline among adults with estimated GFR $>60 \mathrm{~mL} / \mathrm{min} / 1.73 \mathrm{~m}(2)$ : the Multi-Ethnic Study of Atherosclerosis (MESA). Am J Kidney Dis. 2012; 59(1): 41-49, doi: 10.1053/j.ajkd.2011.08.015, indexed in Pubmed: 22000727

34. Kanbay A, Buyukoglan H, Ozdogan N, et al. Obstructive sleep apnea syndrome is related to the progression of chronic kidney disease. Int Urol Nephrol. 2012; 44(2): 535-539, doi: 10.1007/s11255-011-9927-8, indexed in Pubmed: 21369754
35. Chaszczewska-Markowska M, Sagan M, Bogunia-Kubik K. The renin-angiotensin-aldosterone system (RAAS) — physiology and molecular mechanisms of functioning. Post Hig Med Dosw. 2016; 70: 917-927, doi: 10.5604/17322693.1218180.

36. Abuyassin B, Sharma K, Ayas NT, et al. Obstructive sleep apnea and kidney disease: a potential bidirectional relationship? J Clin Sleep Med. 2015; 11(8): 915-924, doi: 10.5664/jcsm.4946, indexed in Pubmed: 25845900.

37. Shlipak MG, Scherzer R, Abraham A, et al. Urinary markers of kidney injury and kidney function decline in HIV-infected women. J Acquir Immune Defic Syndr. 2012; 61(5): 565-573, doi: 10.1097/QAI. Ob013e3182737706, indexed in Pubmed: 23023103.

38. Silverstein DM. Inflammation in chronic kidney disease: role in the progression of renal and cardiovascular disease. Pediatr Nephrol. 2009; 24(8): 1445-1452, doi: 10.1007/s00467-008-1046-0, indexed in Pubmed: 19083024.

39. Zajączkowska MM, Bieniaś B. Aktualny stan wiedzy na temat patogenezy, diagnostyki i leczenia przewlekłej choroby nerek. Med Og Nauk Zdr. 2013; 19(1): 1-7

40. Botros N, Concato J, Mohsenin V, et al. Obstructive sleep apnea as a risk factor for type 2 diabetes. Am J Med. 2009; 122(12): 1122-1127, doi: 10.1016/j.amjmed.2009.04.026, indexed in Pubmed: 19958890.

41. Krajewska O, Skrypnik K, Kręgielska-Narożna M, et al. Wpływ długości i jakości snu na parametry antropometryczne, metaboliczne i ogólny stan zdrowia fizycznego i psychicznego. Forum Zab Metabol. 2017; 8(2): 47-55.

42. Reichmuth KJ, Austin D, Skatrud JB, et al. Association of sleep apnea and type II diabetes: a population-based study. Am J Respir Crit Care Med. 2005; 172(12): 1590-1595, doi: 10.1164/rccm.200504-637OC, indexed in Pubmed: 16192452.

43. Sykut A, Barbara Śl, Jędrzejkiewicz B, et al. Zaburzenia snu jako powszechny problem społeczny - wybrane uwarunkowania i konsekwencje zdrowotne. Pielęgniarstwo XXI wieku. 2017; 16(2): 53-59.

44. Białkowska M. Etiopatogeneza otyłości. Post Nauk Med. 2011; 24(9): 765-769.

45. Pikulska-ChrobakE, WójcikJ, Kozubska M, et al. Znaczenie insulinooporności w rozwoju uszkodzenia nerek. Forum Nefrol. 2017; 10(2): 144-148. 